\title{
Comparative effect of integrated pest management and farmers' standard pest controlpractice for managing insect pests on cabbage (Brassica spp.)
}

\section{Author: Gadi V.P. Reddy}

This is the peer reviewed version of the following article: as cited below in Pest Management Science which has been published in final form at http://dx.doi.org/10.1002/ps.2142. This article may be used for non-commercial purposes in accordance with Wiley Terms and Conditions for Self-Archiving.

Reddy, G.V.P. 2011. Comparative effect of integrated pest management and farmers' standard pest control practice for managing insect pests on cabbage (Brassica spp.). Pest Management Science 67 (8): 980-985. doi: 10.1002/ps.2142 


\title{
Comparative effect of integrated pest management and farmers' standard pest control practice for managing insect pests on cabbage (Brassica spp.)
}

\author{
Gadi VP Reddy* \\ Western Pacific Tropical Research Center, College of Natural and Applied Sciences, University of Guam, Mangilao, Guam, USA
}

\begin{abstract}
BACKGROUND: Studies were conducted on experimental cabbage plantings in 2009 and on experimental and commercial plantings in 2010, comparing farmers' current chemical standard pesticide practices with an integrated pest management (IPM) program based on the use of neem (Aza-Direct) and DiPel (Bacillus thuringiensis). In experimental plantings, the IPM program used six or eight applications of neem and DiPel on a rotational basis. The standard-practice treatments consisted of six or eight applications of carbaryl and malathion or control treatment.

RESULTS: The IPM treatments reduced pest populations and damage, resulting in a better yield than with the standard chemical or control treatment. When IPM treatment included three applications of neem plus three applications of DiPel (on a rotational basis in experimental fields), it again reduced the pest population and damage and produced a better yield than the standard practice. The lower input costs of the IPM program resulted in better economic returns in both trials.
\end{abstract}

CONCLUSIONS: The IPM components neem and DiPel are suitable for use in an IPM program for managing insect pests on cabbage (Brassica spp.).

\section{INTRODUCTION}

In the Mariana Islands, agricultural production has traditionally been for subsistence, and only a few commercial farms exist. Economic development plans in the Marianas call for the development and improvement of market-oriented sustainable agriculture for self-sufficiency, reduced imports and increased local produce. ${ }^{1}$ Although vegetables such as cucumbers, eggplant, bell peppers, green onions and tomatoes have been grown seasonally in the region, head cabbage (Brassica oleracea L. var. capitata) and Chinese cabbage ( $B$. rapa L.) have been grown continuously throughout the year, particularly on Guam, Rota, Saipan and Tinian. Cabbages are often attacked by a number of insect pests, particularly the looper, Chrysodiexis chalcites Esper (Lepidoptera: Noctuidae); the cutworm, Spodoptera litura (Fabricius) (Lepidoptera: Noctuidae); the corn earworm, Helicoverpa armigera (Hübner) (Lepidoptera: Noctuidae); the webworm, Hellula undalis Guenée (Lepidoptera, Pyralidae); the diamondback moth, Plutella xylostella L. (Lepidoptera: Plutellidae); the cluster caterpillar, Crocidolomia pavanana (Fabricius) (Lepidoptera: Pyralidae); the serpentine leaf miner, Liriomyza brassicae Riley (Diptera: Agromyzidae); the fleahopper, Halticus tibialis Reuter (Hemiptera: Miridae); and the cabbage aphid, Brevicoryne brassicae (L.) (Hemiptera: Aphididae). ${ }^{2}$ A major limitation in production occurs with the pest complex consisting of S. litura and L. brassicae, which feed on cabbage. These pests may reduce yield by damaging the heads, causing them to be graded as non-marketable. S. litura is an extremely serious pest, the larvae of which can defoliate many economically important crops in the Pacific. Among the main crop species attacked by S. litura in the tropics are corn, vegetables such as aubergines/eggplant, tomato, Brassica, Capsicum and cucurbit vegetables. Other hosts include ornamentals, wild plants and weeds. Also, the larva of L. brassicae feeds as a leaf miner either on the upper or lower leaf surface and forms a linear serpentine mine. Apparently, the importance of $L$. brassicae can vary through time and space. $L$. brassicae is considered a potentially serious pest both of brassicacean plants and peas. In most of the Pacific region, both of these pests are considered to be extremely damaging agricultural pests.

Farmers in this region apply, in addition to Bacillus thuringienis (DiPel), insecticides such as malathion (55\%) and carbaryl (30\%) as many as $8-10$ times during each cropping period, a regime that not only is financially costly but also has been associated with ecological and toxicological hazards. Ecologically sound and cost-effective integrated pest management (IPM) programs are 
therefore being developed,,$^{3,4}$ and many are being used, ${ }^{5}$ but these programs must be adopted and implemented by farmers. The aim of the project described here was to replace these highrisk insecticides with a combination of a neem-based biopesticide (Aza-Direct) and DiPel, both of which are reported to be effective against many insect pests and have a low environmental impact. Some preliminary tests were carried out in a farmer's cabbage field (that of Mr Francisco M Atalig on Rota), in which neem was used against cabbage insect pests. The chemical was applied (as a spray) 8 times during the cropping period. The incidence of pests in the plot treated with neem was low compared with that in fields treated with DiPel, carbaryl and malathion, and a 30-40\% higher yield of good-quality cabbage was obtained there. Research had therefore begun on whether available alternatives to farmers' current practice with the use of synthetic organic insecticides could be effectively used to produce a marketable cabbage crop.

\section{EXPERIMENTAL METHODS}

\subsection{Cabbage seedlings}

The hybrid cabbage seeds of K-K Cross (American Takii Incorporated, Salinas, CA) were sown in trays $(40 \times 30 \mathrm{~cm})$ and raised in a nursery in the greenhouse $\left(28-30{ }^{\circ} \mathrm{C}, 40-60 \% \mathrm{RH}, 15: 9 \mathrm{~h}\right.$ light: dark photoperiod). The seedlings were grown for 30 days.

\subsection{Field experiments}

Field studies were carried out at two locations of the University of Guam Agricultural Experiment Station: the first at Yigo ( $13^{\circ} 31.930^{\prime}$ $\mathrm{N}, 144^{\circ} 52.351^{\prime}$ E) during September-December 2008, and the second at Inarajan $\left(13^{\circ} 61.963^{\prime} \mathrm{N}, 144^{\circ} 45.353^{\prime} \mathrm{E}\right)$ during January-April 2009.

The treatment plots were $8 \mathrm{~m} \times 8 \mathrm{~m}$ and separated from other plots by $1.5 \mathrm{~m}$ buffer zones designed to avoid spray drift or other treatment effects. Cabbage seedlings raised in the nursery were transplanted to the experimental plots, and all recommended agronomic practices were followed. At each of the two locations, 30-day-old cabbage seedlings were planted with $60 \times 75 \mathrm{~cm}$ spacing. Three replicates, each of 11 treatments, produced a total of 33 plots. Each plot consisted of 12 rows of 12 cabbage plants, for a total of 144 plants per plot. The total area of the experimental cabbage field was $2781 \mathrm{~m}^{2}$ (0.24 acre) at each site.

\subsection{Integrated pest management treatments}

The 11 treatments were applied in a randomized block design, as shown in Table 1.

The concentrations of treatment applications were as follows: Neem (1.2\% azadirachtin) $10 \mathrm{~mL} \mathrm{~L}^{-1}$; DiPel $15 \mathrm{~g} \mathrm{~L}^{-1}$; carbaryl (50\% wettable powder) $43 \mathrm{~g} \mathrm{~L}^{-1}$; malathion (57\% EC) $8 \mathrm{~mL} \mathrm{~L}^{-1}$. The amount of fluid sprayed per application was $93.5 \mathrm{~L} \mathrm{ha}^{-1}$ for small plants (up to $45 \mathrm{DAT}$ ) and $187.0 \mathrm{~L} \mathrm{ha}^{-1}$ for larger ones (45 DAT until harvest). All the chemicals were applied with motorized backpack sprayers (Solo Brand; Forestry Suppliers, Jackson, MS). The sprayer was equipped with an adjustable, flat-spray, hollowcone, jet-stream nozzle, and pressure was calibrated to deliver 20 gpa (185.35 L ha-1) at 45 psi.

\subsection{Comparative effectiveness of IPM and farmers' current practice}

The IPM treatment chosen for comparison with farmers' current practice was three applications of neem alternating with three applications of DiPel, because this treatment combination proved
Table 1. Details of the treatments imposed on cabbage fields at Yigo and Inarajan on Guam

\begin{tabular}{|ll|} 
Treatment & $\begin{array}{l}\text { Timing of treatment } \\
\text { application (days } \\
\text { after transplanting) }\end{array}$ \\
\hline $\begin{array}{l}\text { Control (no applications) } \\
\text { Neem, six applications }\end{array}$ & \multicolumn{1}{c|}{-} \\
Neem, eight applications & $15,30,45,60,75$ and 90 \\
DiPel, six applications & $15,25,35,45,55,65,75$, and 85 \\
$\begin{array}{l}\text { DiPel, eight applications } \\
\text { Neem, three applications, } \\
\quad \text { alternating with DiPel, } \\
\text { three applications }\end{array}$ & $15,30,45,60,75$, and 90 \\
$\begin{array}{l}\text { Neem, four applications, } \\
\text { alternating with DiPel, } \\
\text { four applications }\end{array}$ & $15,25,35,45,55,65,75$, and 85 \\
$\begin{array}{l}\text { Malathion, six applications } \\
\text { Malathion, eight }\end{array}$ & $15,30,45,60,75$, and 90 \\
$\quad$ applications & $15,25,35,45,55,65,75$, and 85 \\
Carbaryl, six applications & $15,30,45,60,75$, and 90 \\
Carbaryl, eight applications & $15,25,35,45,55,65,75$, and 85 \\
\end{tabular}

significantly superior to other treatments in lowering damage and raising marketable yield. For the comparison study, $4047 \mathrm{~m}^{2}$ (1 acre) plots of cabbage field at Yigo (June-September 2009) and Inarajan (October 2009-January 2010) were divided into equal quarters, and these four replicates were subjected to the chosen IPM treatment.

The plots representing farmers' current practice were five $1619 \mathrm{~m}^{2}$ (0.4 acre) plots in cabbage fields owned by different farmers. Three of the plots were located on Guam, one in Dededo $\left(13.52^{\circ} \mathrm{N}, 144.84^{\circ} \mathrm{E}\right.$, June-September 2010), one in Yigo $\left(13.54^{\circ} \mathrm{N}, 144.89^{\circ} \mathrm{E}\right.$, August-November 2009) and one in Merizo (13.27 ${ }^{\circ} \mathrm{N}, 144.67^{\circ} \mathrm{E}$, October 2009-January 2010). The other two plots were in the Northern Mariana Islands, one on Saipan, at Tanapag (15.24 ${ }^{\circ} \mathrm{N}, 145.76^{\circ} \mathrm{E}$, September-December 2009), and the other on Rota, at Sinapalo $\left(14.17^{\circ} \mathrm{N}, 145.24^{\circ} \mathrm{E}\right.$, November 2009-February 2010). Table 2 lists the treatments applied to IPM and current-practice plots. The farmers obtained a variety of insecticides from commercial sources and applied them according to their chosen schedules. The concentrations of treatment sprays used by the farmers were as follows: DiPel $15 \mathrm{~g} \mathrm{~L}^{-1}$; carbaryl $(50 \%$ wettable powder) $43 \mathrm{~g} \mathrm{~L}^{-1}$; malathion (57\% EC) $8 \mathrm{~mL} \mathrm{~L}^{-1}$; lambdacyhalothrin (Warrior 1CS) $15 \mathrm{~mL} \mathrm{~L}^{-1}$. The total amounts of spray fluid per treatment in the farmer's fields ranged from 120 to $210 \mathrm{~L}$ $\mathrm{ha}^{-1}$.

\subsection{Damage and yield assessment}

For both the 2009 and the 2010 studies, sampling was done weekly for 16 weeks. Incidence of attack by S. litura was measured as the number of insects found of each stage (eggs, larvae and pupae) and the number of holes on the leaves, and as the number of larval mines by L. brassicae observed. Ratings of the damage they caused on ten randomly selected plants in each treatment plot were recorded. Each cabbage head was evaluated for head infestation (immature pest stages on the head) and marketability using a standard 1-6 scale. ${ }^{6}$ Similar observations of damage in the farmers' fields were recorded. At the end of the experiment, the crops were harvested and the yield was recorded for each treatment and farm plot. The data were averaged and expressed 
Table 2. Details of the integrated pest management (IPM) and farmers' current practice (FCP) treatments imposed on cabbage fields. The IPM treatments were applied to fields at Yigo and Inarajan on Guam; the FCP treatments were chosen and applied by farmers at Dededo, Yigo and Merizo on Guam, and at Tanapag on Saipan and Sinapalo on Rota. Neem was applied as Aza-Direct. DiPel is a brand name for Bacillus thuringiensis, a bacterial biocontrol agent

\begin{tabular}{|c|c|c|c|c|c|c|}
\hline Days after transplantation & IPM schedule & FCP 1 & FCP 2 & FCP 3 & FCP 4 & FCP 5 \\
\hline 7 & - & DiPel & Malathion & Warrior & - & Carbaryl \\
\hline 14 & Neem & DiPel & DiPel & DiPel & Malathion & Malathion \\
\hline 21 & - & - & Carbaryl & Malathion & - & - \\
\hline 28 & DiPel & DiPel & DiPel & Carbaryl & Malathion & Carbaryl \\
\hline 35 & - & DiPel & DiPel & Carbaryl & Malathion & Carbaryl \\
\hline 42 & Neem & Carbaryl & DiPel & Malathion & Warrior & Carbaryl \\
\hline 49 & - & DiPel & Carbaryl & Carbaryl & Malathion & Malathion \\
\hline 56 & DiPel & DiPel & DiPel & Carbaryl & Warrior & Malathion \\
\hline 63 & - & DiPel & DiPel & Malathion & Malathion & - \\
\hline 70 & Neem & - & Carbaryl & Carbaryl & Warrior & Malathion \\
\hline 77 & - & DiPel & - & Malathion & Malathion & Carbaryl \\
\hline 84 & DiPel & DiPel & DiPel & Malathion & Warrior & - \\
\hline No. applications & 6 & 10 & 11 & 12 & 10 & 9 \\
\hline
\end{tabular}

as the number of larvae and holes and as damage per plant and yield per hectare.

\subsection{Evaluation of occurrence of natural enemies}

Natural enemies (parasitoids and predators) of the pests were also counted for each treatment plot during sampling for the pests. Three cabbage leaves with eggs and ten larvae of S. litura from each plot were collected and incubated, and emergence of parasitoids was noted for measures of parasitism. Similarly, three cabbage leaves heavily infested with $L$. brassicae were collected and examined for any parasitoid emergence. All samples were placed individually in plastic boxes with a perforated top for aeration. They were transported to the laboratory and stored at room temperature until any parasitoids emerged.

\subsection{Economic analysis of investment and benefits}

At the end of the growing period, for each plot, the crop was harvested, the marketable yield was determined and the value of the crop (based on the current market price) was estimated. Here again, each cabbage head was evaluated for head infestation (immature pest stages on the head) and marketability using a standard 1-6 scale. ${ }^{6} \mathrm{~A}$ head was considered marketable if it was free from damage, which corresponds to a rating of 1,2 or 3 on Greene's scale. All data for pest control cost analysis were calculated on a per hectare basis. The costs of the pesticides and their application were as follows: IPM trial 1: neem $=\$ 64.50$, DiPel $=\$ 58.81$ and pesticide application $=\$ 64.73$; IPM trial 2 : neem $=$ $\$ 63.85, \mathrm{DiPel}=\$ 57.86$ and pesticide application $=\$ 68.43 ; \mathrm{FCP}$ $1:$ DiPel $=\$ 105.57$, carbaryl $=\$ 85.60$ and pesticide application $=\$ 74.65 ;$ FCP 2: DiPel $=\$ 90.20$, carbaryl $=\$ 82.14$, malathion $=\$ 48.46$ and pesticide application $=\$ 71.83 ;$ FCP 3: DiPel $=$ $\$ 26.29$, carbaryl $=92.45$, malathion $=\$ 97.08$, Warrior $=\$ 46.54$ and pesticide application $=\$ 82.62 ; \mathrm{FCP} 4$ : malathion $=\$ 172.15$, Warrior $=\$ 101.43$ and pesticide application $=\$ 62.82 ;$ FCP 5: carbaryl $=\$ 92.34$, malathion $=\$ 74.50$ and pesticide application $=\$ 81.06$. The net profit for each plot was determined as the market value of the crop minus the input costs (labor, materials and insecticide application).

\subsection{Statistical analysis}

All the data were analysed by the SAS GLIMMIX procedure in SAS v.9.2. ${ }^{7}$ The data for the holes and leaf mines made by larvae were analyzed with a generalized linear mixed model with a Poisson distribution, and a log-link was used to test the treatment and month effects for these count data. Averages of insect population or damage (holes and mines) on the ten plants in each plot were used as the dependent variable. For yield data (by site), a one-way ANOVA was performed, and, if the treatment effects were significant $(P<0.05)$, mean pairwise comparisons were performed on least squares by the least-squares difference method. If the treatment and/or month effects were significant, pairwise mean comparisons were performed with log-transformed LSMEANS.

\section{RESULTS}

3.1 Damage and yield assessment in the experimental plots Table 3 presents the number of larval S. litura, the number of holes made in leaves by those larvae and the number of mines made by $L$. brassicae on the experimental plots. All three variables were significantly lower $\left(F_{10,279}=155.9, P<0.001\right)$ on IPM treatment (neem plus DiPel) plots than on other plots. The control plots suffered the greatest damage from S. litura and L. brassicae. Results from all other treatments were intermediate.

The marketable yields of cabbage from the IPM plots at both locations were significantly higher than those on other plots $\left(F_{10,22}=\right.$ $1.88, P<0.05$ ) (Table 4). Overall, IPM treatments produced a yield about $50 \%$ higher than that from control plots, but IPM plots receiving six or eight applications did not differ significantly.

\subsection{Damage and yield assessment in the comparison plots}

The mean number of larvae, holes in leaves and leaf mines were all significantly $\left(F_{10,278}=68.58, P<0.05\right)$ (Table 5$)$ lower on the IPM plots than on those managed by farmers' current practices. Damage levels under the different forms of farmers' current practice did not differ significantly.

The average yield from the IPM plot ranged from 37 to $39 \mathrm{t} \mathrm{ha}^{-1}$, whereas that from the farmers' plots ranged from 23 to $28 \mathrm{t} \mathrm{ha}^{-1}$ $\left(F_{10,22}=4.94, P<0.001\right)$ (Fig. 1). Overall averages were $37.2 \mathrm{t}$ $\mathrm{ha}^{-1}$ on IPM plots and $26.02 \mathrm{t} \mathrm{ha}^{-1}$ on farmers' plots. 
Table 3. Mean numbers ( \pm SE) of larvae of Spodoptera litura, holes made by those larvae and mines caused by Liriomyza brassicae recorded per cabbage plant grown on experimental plots at two locations on Guam ${ }^{a}$

\begin{tabular}{|c|c|c|c|c|c|c|}
\hline \multirow[b]{2}{*}{ Treatment } & \multicolumn{3}{|c|}{ Yigo location } & \multicolumn{3}{|c|}{ Inarajan location } \\
\hline & Larvae & Holes & Mines & Larvae & Holes & Mines \\
\hline Control (no applications) & $36.6 \pm 0.5 a$ & $144.5 \pm 0.3 a$ & $61.4 \pm 1.2 b$ & $24.0 \pm 0.6 \mathrm{a}$ & $111.8 \mathrm{a}$ & $56.8 \pm 0.2 b$ \\
\hline Neem, six applications & $3.6 \pm 0.7 c$ & $34.8 \pm 0.5 c$ & $2.7 \pm 1.8 c$ & $2.8 \pm 0.3 c$ & $27.8 \mathrm{C}$ & $2.4 \pm 0.6 \mathrm{c}$ \\
\hline Neem, eight applications & $3.2 \pm 0.3 c$ & $32.6 \pm 0.2 c$ & $2.4 \pm 0.5 c$ & $3.6 \pm 1.2 c$ & $25.1 \mathrm{c}$ & $2.1 \pm 1.4 \mathrm{c}$ \\
\hline DiPel, six applications & $2.7 \pm 1.2 c$ & $35.3 \pm 1.3 c$ & $8.4 \pm 1.0 \mathrm{a}$ & $3.1 \pm 0.8 c$ & $26.6 \mathrm{c}$ & $7.8 \pm 0.2 \mathrm{a}$ \\
\hline DiPel, eight applications & $2.4 \pm 0.8 c$ & $33.6 \pm 0.9 c$ & $9.1 \pm 1.4 \mathrm{a}$ & $3.6 \pm 1.3 c$ & $26.4 \mathrm{c}$ & $8.2 \pm 2.3 \mathrm{a}$ \\
\hline $\begin{array}{l}\text { Neem, three applications, } \\
\text { alternating with DiPel, three } \\
\text { applications }\end{array}$ & $0.5 \pm 0.1 d$ & $1.5 \pm 0.2 \mathrm{~d}$ & $0.2 \pm 0.3 d$ & $0.4 \pm 0.2 d$ & $0.0 \mathrm{~d}$ & $0.0 \pm 0.0 \mathrm{~d}$ \\
\hline $\begin{array}{l}\text { Neem, four applications, alternating } \\
\text { with DiPel, four applications }\end{array}$ & $0.4 \pm 0.2 d$ & $0.5 \pm 0.1 \mathrm{~d}$ & $0.0 \pm 0.0 \mathrm{~d}$ & $0.0 \pm 0.0 \mathrm{~d}$ & $0.0 \mathrm{~d}$ & $0.0 \pm 0.0 \mathrm{~d}$ \\
\hline Malathion, six applications & $3.5 \pm 1.3 c$ & $34.2 \pm 1.2 \mathrm{c}$ & $6.2 \pm 2.1 \mathrm{e}$ & $5.3 \pm 0.2 \mathrm{e}$ & $27.5 \mathrm{c}$ & $4.4 \pm 1.5 \mathrm{e}$ \\
\hline Malathion, eight applications & $2.8 \pm 0.5 c$ & $32.5 \pm 0.8 c$ & $6.0 \pm 1.4 \mathrm{e}$ & $5.8 \pm 0.6 \mathrm{e}$ & $31.2 \mathrm{e}$ & $3.9 \pm 1.7 \mathrm{e}$ \\
\hline Carbaryl, six applications & $6.6 \pm 0.6 \mathrm{e}$ & $38.2 \pm 0.7 \mathrm{e}$ & $3.2 \pm 0.8 c$ & $6.2 \pm 0.5 \mathrm{e}$ & $33.4 \mathrm{e}$ & $4.2 \pm 1.6 \mathrm{e}$ \\
\hline Carbaryl, eight applications & $5.8 \pm 0.4 \mathrm{e}$ & $36.4 \pm 0.6 \mathrm{e}$ & $2.8 \pm 0.4 c$ & $5.7 \pm 1.3 \mathrm{e}$ & $32.7 \mathrm{e}$ & $4.1 \pm 2.2 \mathrm{e}$ \\
\hline
\end{tabular}

${ }^{a}$ Means within each column followed by the same letter are not significantly different at the $P<0.05$ level (generalized linear mixed model using the Poisson distribution followed by pairwise mean comparisons). Each treatment was replicated 3 times.

\begin{tabular}{|c|c|c|}
\hline \multirow[b]{2}{*}{ Treatment } & \multicolumn{2}{|c|}{ Marketable yield $\left(\mathrm{t} \mathrm{ha}^{-1}\right)$} \\
\hline & Yigo location & Inarajan location \\
\hline Control (no applications) & $12.8 \pm 1.6 \mathrm{a}$ & $15.2 \pm 1.2 \mathrm{a}$ \\
\hline Neem, six applications & $28.6 \pm 0.4 b$ & $29.2 \pm 1.3 b$ \\
\hline Neem, eight applications & $29.4 \pm 1.2 b$ & $29.6 \pm 0.7 b$ \\
\hline DiPel, six applications & $26.5 \pm 1.1 \mathrm{~b}$ & $25.6 \pm 0.3 c$ \\
\hline DiPel, eight applications & $27.6 \pm 0.9 b$ & $24.8 \pm 0.8 c$ \\
\hline $\begin{array}{l}\text { Neem, three applications, } \\
\text { alternating with DiPel, } \\
\text { three applications }\end{array}$ & $36.2 \pm 1.4 \mathrm{~d}$ & $34.1 \pm 0.7 \mathrm{~d}$ \\
\hline $\begin{array}{l}\text { Neem, four applications, } \\
\text { alternating with DiPel, } \\
\text { four applications }\end{array}$ & $35.3 \pm 1.6 d$ & $36.6 \pm 0.9 d$ \\
\hline Malathion, six applications & $27.3 \pm 0.6 b$ & $26.8 \pm 0.6 c$ \\
\hline $\begin{array}{l}\text { Malathion, eight } \\
\text { applications }\end{array}$ & $28.2 \pm 0.2 b$ & $25.6 \pm 1.3 c$ \\
\hline Carbaryl, six applications & $24.3 \pm 0.4 c$ & $24.6 \pm 1.6 c$ \\
\hline Carbaryl, eight applications & $22.2 \pm 0.6 c$ & $24.3 \pm 0.8 c$ \\
\hline \multicolumn{3}{|c|}{$\begin{array}{l}\text { a Means within each column followed by different letters are } \\
\text { significantly different at the } P<0.05 \text { level (one-way ANOVA followed } \\
\text { by LSMEANS by the least-squares difference method). Each treatment } \\
\text { was replicated } 3 \text { times. }\end{array}$} \\
\hline
\end{tabular}

\subsection{Occurrence of natural enemies}

No parasitoids or predators emerged from the field samples collected during the experimental period.

\subsection{Economic analysis of investments and benefits}

Costs incurred on the IPM plots averaged $\$ 189.09 \mathrm{ha}^{-1}$; those on farmers' plots averaged $\$ 298.34 \mathrm{ha}^{-1}$. The gross value of the harvest from the IPM plots was nearly $\$ 1000 \mathrm{ha}^{-1}$ more than that of the farmers' plots (Table 6).
Table 5. Mean numbers ( \pm SE) of larvae of Spodoptera litura, holes in leaves caused by those larvae and mines caused by Liriomyza brassicae on cabbage fields subjected to the IPM and FCP regimes described in Table $1^{\text {a }}$

\begin{tabular}{|lrrr|}
\hline \multicolumn{1}{l}{ Treatments } & \multicolumn{1}{c}{ Larvae } & Holes & \multicolumn{1}{c|}{ Mines } \\
\hline IPM Trial 1, Yigo & $1.2 \pm 0.4 \mathrm{a}$ & $2.3 \pm 0.5 \mathrm{a}$ & $0.8 \pm 0.6 \mathrm{a}$ \\
IPM, Trial 2, Inarajan & $0.8 \pm 1.1 \mathrm{a}$ & $1.2 \pm 0.3 \mathrm{a}$ & $0.3 \pm 0.1 \mathrm{a}$ \\
FCP 1 & $9.3 \pm 0.3 \mathrm{~b}$ & $28.2 \pm 0.6 \mathrm{~b}$ & $12.6 \pm 0.5 \mathrm{~b}$ \\
FCP 2 & $10.6 \pm 1.3 \mathrm{~b}$ & $31.7 \pm 1.8 \mathrm{~b}$ & $9.8 \pm 1.0 \mathrm{~b}$ \\
FCP 3 & $8.9 \pm 0.7 \mathrm{~b}$ & $34.6 \pm 1.3 \mathrm{~b}$ & $11.3 \pm 1.4 \mathrm{~b}$ \\
FCP 4 & $11.3 \pm 0.3 \mathrm{~b}$ & $33.6 \pm 0.7 \mathrm{~b}$ & $10.8 \pm 0.3 \mathrm{~b}$ \\
FCP 5 & $9.5 \pm 0.7 \mathrm{~b}$ & $32.8 \pm 0.4 \mathrm{~b}$ & $9.7 \pm 0.0 \mathrm{~b}$ \\
\hline \multicolumn{4}{l}{ a Means within each column followed by the same letter are not } \\
significantly different at the $P<0.05$ level (generalized linear mixed \\
model with the Poisson distribution followed by pairwise mean \\
comparisons). Each treatment was replicated 3 times.
\end{tabular}

\section{DISCUSSION}

Using IPM and other newer strategies to replace toxic chemical sprays for better pest control has been considered a top priority for sustainable agriculture in the new century. In this paper, studies not only on the insect control effects of an IPM practice versus farmers' standard practice but also on the economics of both practices have been reported. Although conservation of natural enemies is one of the goals of an IPM program (to achieve high levels of predation or parasitism to aid in pest management), no natural enemies were recorded in the present study. This could be due to prolonged use of toxic chemicals in the region. However, the goal of conservation of natural enemies can be accomplished through the use of reduced-risk insecticides. ${ }^{8}$ Moreover, the reduced-risk insecticides have demonstrated high levels of pest control while diminishing deleterious effects on beneficial insects. ${ }^{9,10}$

Researchers have attempted to reduce insecticide usage in cabbage by developing action thresholds for pests on cabbage on the basis of sampling immature stages on leaves. ${ }^{11}$ While these 

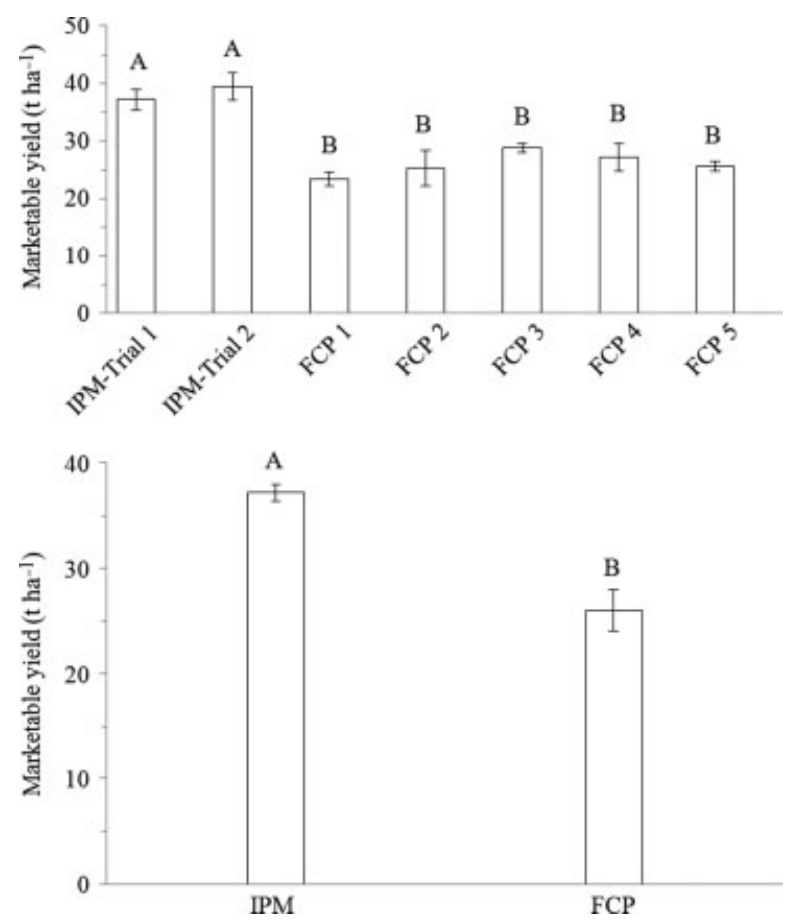

Figure 1. Marketable yields of cabbage from fields subjected to the treatments described in Table 1. Means marked by different letters are significantly different at the $P<0.05$ level (one-way ANOVA followed by LSMEANS with the least-squares difference method). FCP: farmers' current practice.

action-threshold-based insecticide spray regimens can be used to replace the existing calendar-based spray regimen currently used to manage pests on cabbage in the Pacific, thresholds vary considerably among regions. A research-based action threshold that is appropriate for timing insecticide applications to control pests in Micronesian cabbage fields has not been identified. The findings from the present study are based on large-plot experiments, and these results are assumed to work well in largescale, commercial production in Micronesia.

Although, as the present study demonstrated, the farmers' practice of using the insecticides carbaryl and malathion was effective in reducing the $S$. litura larval population and the damage it causes, as well as the number of mines caused by L. brassicae, and produced yields significantly higher than those of the control plots, these insecticides have serious disadvantages. Both are toxic to fish ${ }^{12}$ and bees, ${ }^{13}$ and both can be hazardous to human health during application if not handled carefully. ${ }^{14}$ Because they are broad-spectrum insecticides, they are toxic to beneficial insects as well as to pests, ${ }^{15}$ so their overuse can lead to outbreaks of aphids and spider mites. ${ }^{16,17}$ Because carbaryl is one of the most frequently used carbamate insecticides and is widely used for the control of a variety of pests on fruit, vegetables, forage and many other crops in the Pacific and other parts of the world, this problem could be serious. ${ }^{18}$

A possible alternative is the use of microbial agents such as DiPel, a primary biocontrol agent of insect pests. ${ }^{19}$ Kurstaki (DiPel DF) is another bacterium well known for suppression of a variety of insect pests. It is effective against caterpillars: the cabbage looper, cabbageworm, grape leaffolder, hornworm, cutworm, sod webworm, tobacco budworm and several other lepidopterous species..$^{20}$ In the present study, DiPel was toxic only to caterpillars and proved no more effective, and sometimes less effective, than malathion and carbaryl. Prior studies strongly support the use of DiPel in IPM programs for the control of Plutella xylostella on cabbage ${ }^{4}$ and Helicoverpa armigera on cotton, ${ }^{21}$ but many $B$. thuringienis products are known to break down quickly in sunlight. ${ }^{22}$ Because the weather in Micronesia is sunny, humid and hot throughout the year, depending solely on DiPel to control insect pests is not advisable.

In the present study, the neem-based product Aza-Direct was shown to be significantly more effective than the control when it was used alone. In the last decade, plant extracts with insecticidal properties have evoked substantial scientific and practical interest as natural means of insect and mite pest control in agriculture. While the seeds contain most of the principal active ingredient (azadirachtin), the leaves and other tree parts also contain significant amounts. ${ }^{23}$ Neem trees produce several terpenoid compounds with insect antifeedant and growth-regulating properties and show only low toxicity towards mammals and other vertebrates. A neem-based insecticide is an ideal candidate for inclusion in IPM programs ${ }^{4}$ because of its low toxicity to natural enemies ${ }^{21}$ of pests and its safety in the environment. Furthermore, no phytotoxicity has been observed in any plant tissues. ${ }^{24}$ Neem is also less toxic to insect pollinators. ${ }^{25}$ Neem biopesticides may therefore be well suited for inclusion in IPM programs, 4,21,25 but their known lack of rapid knockdown poses a challenge for promoting neem in pest control markets, where people have come to expect instantaneous results. ${ }^{26}$ The alternation of neem with DiPel, as evaluated in the present study, is cheaper than the use of synthetic organic insecticides primarily because of the lower number of applications needed to control $S$. litura and $L$. brassicae. The resulting higher crop yields further increased the cost effectiveness of the IPM treatments. The $\$ 671.72$

Table 6. Costs and revenues from the cabbage fields described in Tables 1 and 4. IPM and economic analysis of investment versus benefit in the IPM program and farmers' practice ${ }^{a}$

\begin{tabular}{|c|c|c|c|c|}
\hline Treatments & Number of applications & Pest-control costs $\left(\$ \mathrm{ha}^{-1}\right)$ & Gross revenue $\left(\$ \mathrm{ha}^{-1}\right)$ & Net revenue $\left(\$ \mathrm{ha}^{-1}\right)$ \\
\hline IPM, trial 1, Yigo & 6 & 188.04 & 4043.40 & 1042.42 \\
\hline IPM, trial 2, Inarajan & 6 & 190.14 & 4018.23 & 998.12 \\
\hline FCP 1 & 10 & 265.82 & 3624.20 & 342.40 \\
\hline FCP 2 & 11 & 292.63 & 3712.54 & 318.12 \\
\hline FCP 3 & 12 & 344.98 & 2986.32 & 298.13 \\
\hline FCP 4 & 10 & 340.40 & 3526.17 & 368.12 \\
\hline FCP 5 & 9 & 247.90 & 3482.24 & 416.00 \\
\hline
\end{tabular}


difference between the net value of the harvest on IPM plots and that on farmers' plots demonstrates the obvious advantage of IPM over the farmers' current practices. The present results are consistent with those of Burkness and Hutchison ${ }^{8}$ who reported that an IPM program (with either spinosad or indoxacard) resulted in a significantly lower percentage of infected cabbage plants than did the conventional program or an untreated control. These results differ somewhat from those of Edelson et al. ${ }^{3}$ who reported that the greater number of applications of biorational techniques [B. thuringiensis and/or fatty acid soap applications and inundate releases of Chrysoperla carnea (Neuroptera: Chrysopidae)] required for effective control of insect pests on broccoli frequently caused these biorational treatments to be more costly than the synthetic organic insecticides. The IPM approach of alternating neem and DiPel can keep pests from causing significant problems, with minimum risk to humans and the desirable components of their environment. This kind of approach can be expected to continue to be a dominant theme in agriculture. ${ }^{27}$

\section{CONCLUSIONS}

An IPM regime consisting of commercially available products (neem and DiPel), applied alternately, was cost competitive for management of the pest complex attacking cabbage crops on Guam. This regime should be promoted among the Pacific islands and other parts of the tropical world.

\section{ACKNOWLEDGEMENTS}

This project was supported by the FY 2008 Pacific Islands Area Conservation Innovation Grants (PIA-CIG) Program, Grant Agreement No. 69-9251-8-793, The Natural Resources Conservation Service (NRCS)-USDA. In accordance with federal law and USDA policy, this institution is prohibited from discrimination on the basis of race, color, national origin, sex, age or disability. This work benefited from support in the field from ZT Cruz, F Naz, N Braganza, J Remolona, R Kikuchi and R Gumataotao. The author thanks Michael Whitt, Resource Conservationist (USDA-NRCS Pacific Islands Area, Hawaii), and Dr Craig Smith, Conservation Agronomist (USDANRCS Pacific Islands West Area, Guam), for their encouragement and support during all phases of the project.

\section{REFERENCES}

1 Osman WM, Guam economic report. Bank of Hawaii, Honolulu, HI, 16 pp. (1995).

2 Muniappan R and Marutani M, Pest management for head cabbage production on Guam, in Proceedings of the Second International Workshop on Management of Diamondback Moth and Other Crucifer Pests, ed. by Talekar NS. Tainan, Taiwan, pp. 541 -549 (1992).

3 Edelson JV, Magaro JJ and Browning H, Control of insect pests on broccoli in southern Texas: a comparison between synthetic organic and biorational treatments. J Entomol Sci 28:191-196 (1993).

4 Reddy GVP and Guerrero A, Pheromone-based integrated pest management to control the diamondback moth Plutella xylostella in cabbage fields. Pest Manag Sci 56:882-888 (2000).

5 Endersby NM and Morgan WC, Alternatives to synthetic chemical insecticides for use in crucifer crops. Biol Agric Hort 8:33-52 (1991).

6 Greene GL, Genung WG, Workman RB and Kelsheimer EG, Cabbage looper control in Florida - a cooperative program. J Econ Entomol 62:798-800 (1969).
7 SAS/STAT 9.3 User's Guide. SAS Institute, Cary, NC (2009).

8 Burkness EC and Hutchison WD, Implementing reduced-risk integrated pest management in fresh-market cabbage: improved net returns via scouting and timing of effective control. $J$ Econ Entomol 101:461-471 (2008).

9 Hill TA and Foster RE, Influence of selected insecticides on the population dynamics of diamondback moth (Lepidoptera: Plutellidae) and its parasitoid, Diadegma insulare (Hymenoptera: Ichneumonidae), in cabbage. J Entomol Sci 38:59-71 (2003).

10 Hutchison WD, Bartels DW and Bolin PC, Biorational alternatives to insect control in cabbage, in Proceedings, 1999 Midwest Food Processors Assoc. Conference, 2-4 February 1993, La Crosse, WI, ed. by Hughes RL and Michaelis BA. University of Wisconsin Extension Service, Madison, WI, pp. 9-19 (1993).

11 Hines RL and Hutchison WD, Evaluation of action thresholds and spinosad for lepidopteran pest management in Minnesota cabbage. J Econ Entomol 94:190-196 (2001).

12 Beyers DW, Keefe TJ and Carlson CA, Toxicity of carbaryl and malathion to two federally endangered fishes, as estimated by regression and ANOVA. Environ Toxic Chem 13:101-107 (1994).

13 Johansen CA, Mayer DF, Eves JD and Kious CW, Pesticides and bees. Environ Entomol 12:1513-1518 (1983).

14 Shehata T, Richardson E and Cotton E, Assessment of human population exposure to carbaryl from the 1982 Main spruce budworm spray project. J Environ Health 46:293-297 (1984).

15 Wilkinson JD, Biever KD and Ignoffo CM, Contact toxicity of some chemical and biological pesticides to several insect parasitoids and predators. BioControl 20:1386-6141 (1975).

16 Goyal M, The spidermite Tetranychus telarious L. (Tetranychidae: Acarina) on glass house brinjal, Solanum melongena. Sci Cul 48:220-221 (1982).

17 Reddy GVP, Comparative effectiveness of an integrated pest management system and other control tactics for managing spider mite Tetranychus /udeni (Acari:Tetranychidae) on eggplant. Exp Appl Acarol 25:985-992 (2001).

18 Mathew L, Reddy MLP, Rao TP, lyer CSP and Damodaran AC, Simple spectrophotometric method for the determination of carbaryl in soil and insecticide formulations. Analyst 120:1799-1801 (1995).

19 Miller JC, Field assessment of the effects of a microbial pest control agent on non-target Lepidoptera. Am Entomol 36:135-139 (1990).

20 Ibargutxi MA, Estela A, Ferre J and Caballero P, Use of Bacillus thuringiensis toxins for control of the cotton pest Earias insulana (Boisd.) (Lepidoptera: Noctuidae). Appl Envir Microbiol 72:437-442 (2006).

21 Reddy GVP and Manjunatha M, Laboratory and field studies on the integrated pest management of Helicoverpa armigera on cotton, based on pheromone trap catch threshold level. J Appl Entomol 124:213-221 (2000).

22 Siegel JP, Lacey LL and Kaya HK (eds), Bacteria, in Field Manual of Techniques in Invertebrate Pathology. Kluwer Academic Publishers, Dordrecht, The Netherlands, pp. 209-230 (2000).

23 Sutherland JP, Baharally V and Permaul D, Use of botanical insecticide, neem, to control the small rice stinkbug Oebalus poecilus (Dallas, 1851) (Hemiptera: Pentatomidae) in Guyana. Entomotropica 17:97-101 (2002).

24 Xuan TD, Eiji T, Hiroyuki T, Mitsuhiro M, Khanh TD and Chung I, Evaluation on phytotoxicity of neem (Azadirachta indica A. Juss) to crops and weeds. Crop Prot 23:335-345 (2004).

25 Koul O and Wahab S, Neem: Today and in the New Millennium. Kluwer Academic Publishers, Dordrecht, The Netherlands, 276 pp. (2004).

26 Vietmeyer ND, Neem: a tree for solving global problems. Report of an ad hoc panel of the Board on Science and Technology for International Development, National Research Council, National Academy Press, Washington, DC, pp. 74-75 (1992).

27 Ehler LE, Integrated pest management (IPM): definition, historical development and implementation, and the other IPM. Pest Manag Sci 62:787-789 (2006). 